\title{
Effect of Health Workers Sensitization on Satisfaction with Immunization Services among Mothers of Under Fives In Ilorin, North Central Nigeria
}

\author{
Goodman OO. ${ }^{1}$, Aderibigbe SA. ${ }^{2}$, Sekoni OO. ${ }^{3}$, Olatona FA. ${ }^{4}$, Kuyinu YA. ${ }^{1}$

\begin{abstract}
Objective: Patients' satisfaction is a useful measure of the quality of service. An expression of satisfaction or dissatisfaction is also the patients' judgment on the quality of service in all its aspects. This study examined the effect of health workers sensitization on mothers' satisfaction with immunization service provided in health care facilities in a state in North Central Nigeria.
\end{abstract}

Methods: This is a quasi-experimental study involving sensitization of health workers on quality health service provision at the study site, Alanamu Health Centre, Ilorin. The control group was at Okelele Health Centre, Ilorin. One hundred and fifty mothers were recruited from each of the facilities and the total population of mothers bringing their children (0-14 weeks old) for immunization was recruitedconsecutively for the study.

Results: Less than $80 \%$ of respondents in the study group and the control group $(73.3 \%$ and $77.3 \%$ respectively) were satisfied with the waiting time at the pre-intervention stage. At post-intervention, there was a significant increase in the proportion of mothers in the study group that were satisfied with the waiting time, seat provision and information received on immunization $(\mathrm{p}<0.05)$ while there were no significant changes in satisfaction among mothers in the control group regarding these measures $(p>0.05)$. Age and level of education had significant influence on mothers' satisfaction $(\mathrm{p}<0.05)$.

Conclusion: Mothers became more satisfied with various aspects of immunization service received after sensitization of health workers on quality health service. Sensitization of health workers towards quality health service may be necessary to generate options in service provision and improve client satisfaction.

Keywords: Clients'Satisfaction, Immunization Services, Health Workers Sensitization, Nigeria

\footnotetext{
*Correspondence author: Dr. Aderibigbe S.A. Email: tayonov23@yahoo.com

${ }^{1}$ Dept of Community Health \& Primary Health Care, College of Medicine, Lagos State University, Nigeria. ${ }^{2}$ Dept of Epid \& Community Health, College of Health Sciences, University of Ilorin, Nigeria. ${ }^{3}$ Dept of Preventive and Social Medicine, College of Medicine, University of Ibadan, Nigeria. ${ }^{4}$ Dept of Community Health \& Primary Care, University of Lagos, Nigeria.
} 


\title{
Effet de la sensibilisation des agents de santé sur la satisfaction des services de vaccination chez les mères de moins de cinq ans à Ilorin, centre-nord du Nigeria
}

\author{
Goodman OO. ${ }^{1}$, Aderibigbe SA. ${ }^{2}$, Sekoni OO. ${ }^{3}$, Olatona FA. ${ }^{4}$, Kuyinu YA. ${ }^{1}$
}

\section{Resume}

Objectif: La satisfaction des patients est une mesure utile de la qualité du service. Une expression de satisfaction ou d'insatisfaction est aussi le jugement des patients sur la qualité du service sous tous ses aspects. Cette étude a examiné l'effet de la sensibilisation des agents de santé sur la satisfaction des mères à l'égard du service de vaccination dispensé dans les établissements de soins de santé d'un État du centrenord du Nigéria.

Méthodes: Il s'agit d'une étude quasi expérimentale portant sur la sensibilisation des agents de santé à la prestation de services de santé de qualité sur le site de l'étude, Alanamu Health Centre, Ilorin. Le groupe témoin était au Okelele Health Centre, Ilorin. Cent cinquante mères ont été recrutées à partir de chacune des installations et la population totale de mères amenant leurs enfants (0-14 semaines) pour la vaccination a été recrutéeconsécutivement pour l'étude.

Résultats: Moins de $80 \%$ des répondants du groupe d'étude et du groupe témoin $(73,3 \%$ et $77,3 \%$, respectivement) étaient satisfaits du temps d'attente au stade pré-intervention. À la suite de l'intervention, on a noté une augmentation significative de la proportion de mères dans le groupe d'étude qui étaient satisfaites du temps d'attente, de la disponibilité du siège et de l'information reçue sur la vaccination ( $\mathrm{p}$ $<0,05)$ Le groupe témoin en ce qui concerne ces mesures ( $p>0,05)$. L'âge et le niveau d'instruction ont eu une influence significative sur la satisfaction des mères $(\mathrm{p}<0,05)$.

Conclusion: Les mères sont devenues plus satisfaites des divers aspects des services de vaccination reçus après la sensibilisation des agents de santé à des services de santé de qualité. La sensibilisation des agents de santé à des services de santé de qualité peut être nécessaire pour générer des options dans la prestation de services et améliorer la satisfaction de la clientèle.

Mots-clés: Satisfaction des clients, Services de vaccination, Sensibilisation des travailleurs de la santé, Nigéria

\footnotetext{
*Auteur correspondant: Dr. Aderibigbe S.A.Email: tayonov23@yahoo.com

${ }^{1}$ Dept of Community Health \& Primary Health Care, College of Medicine, Lagos State University, Nigeria.

${ }^{2}$ Dept of Epid \& Community Health, College of Health Sciences, University of Ilorin, Nigeria.

${ }^{3}$ Dept of Preventive and Social Medicine, College of Medicine, University of Ibadan, Nigeria.

${ }^{4}$ Dept of Community Health \& Primary Care, University of Lagos, Nigeria.
} 


\section{INTRODUCTION}

Patients' satisfaction is a useful measure of the quality of service and it is considered to be one of the desired outcomes of care and even an element in health status itself (1). The information from which inferences about quality of service can be drawn and can be classified under three categories: Structure, process and outcome. Client satisfaction is an important outcome measure and it may be a predictor of whether patients re-attend the clinic to obtain services $(3,4)$. An expression of satisfaction or dissatisfaction is also the patients' judgment on the quality of service in all its aspects (5).

In the past two decades, there has been a growing recognition of client satisfaction of health service which has led to increased research in this area (6-9). Previous studies have shown that consumers of health services appraise factors such as courtesy, responsiveness, attentiveness, waiting time, availability of vaccine and some patients even consider these more important than the technical competence (9-11). Provider behavior, especially respect and courtesy have been found to be an important predictor of client satisfaction (5).

However, there have been arguments that patient feedback is not credible because of patients lack knowledge of technical quality (11), but recent thinking is that if these patient feedback measures address a specific event or visit, focus on provider- patient interactions, and are assessed in a timely manner, they seem to capture an important and otherwise unmeasured dimension of quality of care (12). It has been suggested that the debate should not center on whether patients can provide meaningful quality measures but on how to improve patient experiences by focusing on activities (such as care coordination and patient engagement) found to be associated with both satisfaction and outcomes (12).

Immunization remains the most cost effective strategy to reducing childhood morbidity and mortality occurring from vaccine preventable diseases. Immunization services are made available at primary health facilities in Nigeria and the national schedule is at birth, 6 weeks, 10 weeks, 14 weeks, 6 months and 9 months of age. This study therefore aimed to determine the effect of health workers' sensitization to quality health care service provision on mothers' satisfaction with immunization service provided in two primary health care facilities in Ilorin, North Central
Nigeria.

\section{MATERIALSAND METHODS}

This was a quasi-experimental study that was carried out in three stages: Pre-intervention, intervention and post-intervention stages in Ilorin. Ilorin can be described as an emerging city with 3 local government areas (LGAs) and a population of 847,582(13). Children under 1 year of age are estimated to be $3.31 \%$ of the population while children under five years of age constitute about $13.12 \%$ of the population (14). Ilorin metropolis has one tertiary health institution, two secondary health institutions, nine primary health facilities and one hundred and eleven privately owned hospitals.

Alanamu Health Centre, where the study was conducted, is a primary health facility located in Ilorin West LGA. It serves as a fixed site for immunization and it provides other services such as maternal services, family planning, growth monitoring, food demonstration and general outpatient consultations. The control site is at the Okelele Health Center located in Ilorin East LGA. It is also a fixed site for immunization and provides other services such as maternal services, family planning, growth monitoring, food demonstration and general outpatient consultations. Alanamu Health Centre and Okelele Health Centre both offer immunization service once a week.

The study population was mothers of children who were receiving immunization at these health facilities. A sample size of 150 each (for study group and control group) was calculated using the formula for estimating sample size in comparison of two proportions (15).

Inclusion criteria: Mothers bringing infants (014 weeks old) for immunization were consecutively recruited into the study until sample size was reached for both groups. This made it easy to get a cohort of mothers attending the clinic at the same time, and as such expected to be due for revisit at the same time.

Mothers that were unwilling to participate in the study were excluded from the study. The study duration was 10 months.

The instrument of data collection was a structured questionnaire which was administered by 3 trained research assistants and the researcher. The questionnaire was pretested in a health facility in Ilorin south LGA. The 
questionnaire was administered to mothers at the pre- Intervention stage and post- Intervention stages as exit interviews.

At Pre-Intervention, the questionnaire was administered to both the study and control groups to generate quantitative data. The serial number on the questionnaire was indicated on the immunization card. Phone numbers and address were also indicated on the questionnaire to ensure that the same mothers were also interviewed at post intervention.

At Intervention, there was sensitization of health workers at Alanamu Health Centre where the study group was. The health workers sensitized were nurses, $\mathrm{CHO}$ and CHEWs because they were the ones involved in immunization. Other health workers such as the laboratory technicians, pharmacy technicians, attendants and other hospital workers that were not involved with immunization were not sensitized. The sensitization involved all 18 health workers in the facility (with the exception of one who was on leave), over the span of two days (to make provision for those on shift duties and those that were not present on the first day).

The sensitization focused on improving quality of immunization service and client satisfaction at the health center based on findings from the perspectives of mothers of children attending the immunization clinic (findings were from the data collected at the pre-intervention). The sensitization addressed waiting times of mothers, adequate seat provision, attitude of health workers towards mothers, provision of information regarding number of visits due to complete immunization, immunization due for the day, possible side effects, information on what to do if there are side effects and information on when to return for next appointment. It was agreed that immunization sessions be held twice a week in order to improve client satisfaction in terms of waiting time, sitting arrangements and provision of better interaction between health workers and the mothers. An extra day was therefore added to the one day that had previously existed as an immunization day. Role plays and discussions were used to emphasize the issues raised and to encourage participation of the health workers. The sensitization took place within Alanamu health center facility.

The post intervention was done three months after the intervention to allow for changes to occur in quality of service delivery. The same questionnaire used in the pre-intervention stage was administered again as exit interviews to both study and control groups to evaluate the effect of sensitization of health workers on satisfaction with immunization services among mothers of children attending the clinic. The same mothers interviewed at the pre intervention were also interviewed at post intervention in both the study and the control groups.

The study group included 150 mothers bringing their children for immunization at Alanamu Health Centre, Ilorin and the control group also included 150 mothers bringing their children for immunization at Okelele Health Centre.

Data collation and editing was done manually to detect omission and ensure uniform coding. The analysis was done using EPI INFO version 6.0, frequency tables and cross tabulations generated. Two stage analysis was done; analysis of the pre-intervention questionnaires and the post-intervention questionnaires. Satisfaction or dissatisfaction was based on the mothers'responses and satisfaction was further graded as: Excellent, very good, good, fair and poor. Chi-square test was used to compare proportions and Yates correction was used in instances where values were less than 5. A p- value of less than 0.05 was considered as statistically significant.

Ethical approval for the study was obtained from the ethical committee of the University of Ilorin Teaching Hospital. Mothers' consent was obtained before interview and nature of study was made clear. For ethical reasons, sensitization was carried out at Okelele health centre after the post intervention data had been collected.

\section{RESULTS}

The respondents' ages ranged from 16 to 48 years. The mean age of the study respondents was $28.5 \pm 5.2$ years and the modal age group was 26-30 years. The mean age of the control respondents was $26.7 \pm 4.9$ years and the modal age group was 26-30 years. Majority of the respondents in both the study and the control groups had at least 3 children $72.7 \%$ and $73.4 \%$ respectively. Forty two percent $(42.7 \%)$ of respondents in study group and $53.3 \%$ of the control group were traders. Only a few of the respondents $7.3 \%$ of study and $4.7 \%$ of the control group were housewives. Other occupation which accounted for $14 \%$ of study and $18 \%$ of the control included hairdressing, farming, butchering, cloth weaving and shop attendant. 
Majority of the respondents $(63.3 \%$ and $62,7 \%$ of the study and control groups respectively) had at least primary education and majority $(82.7 \%$ in the study group and $90.0 \%$ in the control group) were Yoruba. The other ethnic groups included tribes like the Nupe, Ebira, Igala and Urobo. Islam was the predominant religion as $84.0 \%$ of the study group and $92.0 \%$ of the control group were muslims. Majority of the respondents were married in both the study and the control groups $(96.7 \%$ and $94.0 \%$ respectively. The socio-demographic characteristics of both the study and control groups were similar as there was no significant difference in their socio-demographic characteristic $(p>0.05)$ (Table 1$)$.

Mean waiting time was $82.1 \pm 32.5$ minutes and $90.4 \pm 41.7$ minutes for the study and control groups respectively at the preintervention stage. At post- intervention, mean waiting time in the study group was $48.0 \pm 24.4$ minutes while that of the control group was $88.4 \pm$ 40.6 minutes. Less than $80 \%$ of respondents in both study and control groups were satisfied with waiting time at pre-intervention stage. However, at post-intervention, there was a significant increase in proportion of satisfied mothers with the waiting time $(p<0.05)$ in the study group and no significant difference in the control group. Seventy six percent $(76.7 \%)$ of respondents in the study group were satisfied with seats provision at pre-intervention while $94.7 \%$ of respondents in control group were satisfied with seat provision. There was a significant increase in proportion of mothers satisfied with seat provision in the study group $(\mathrm{P}<0.05)$ while there was no significant change in the control group. More than $85 \%$ of mothers in both the study and control groups (91.3\% and $89.3 \%$ respectively) were satisfied with information they had received on immunization at pre-intervention, but only the study group witnessed a significant increase in proportion of satisfied mothers at postintervention $(\mathrm{P}<0.05)$. In the study group at preintervention, $96.0 \%$ of mothers were satisfied with the way they were treated by the health workers and $98 \%$ were satisfied with the overall service they had received in the facility at that visit but these had no significant change at post intervention in the study group. Similarly, in the control group at pre-intervention, $96.7 \%$ of mothers were satisfied with the way they were treated by the health worker while $98 \%$ of the mothers were satisfied with the overall service they had received at the visit. However, there were no significant changes at post-intervention in the control group in the proportions of mothers satisfied with the way they were treated by the health workers and in their overall satisfaction with the service they had received on the visit (Table 2).

Among socio-demographic factors, age and level of education were significantly related to whether or not a respondent was satisfied with the service she had received in both the study and control groups $(\mathrm{p}<0.05)$. (Table 3$)$

At pre-intervention, less than $15 \%$ of respondents in both study and control groups (10.7\% and $9.3 \%$ respectively) had rated their level of satisfaction as "Excellent" and less than $50 \%$ of the respondents $(46 \%$ of study group and $48.6 \%$ of control group) had rated their satisfaction as either "Excellent" or "Very good". At post intervention, there was a better rating of respondents' satisfaction which was significant $(\mathrm{P}<0.05)$ in the study group. Ninety one percent $(91.0 \%)$ of respondents rated their satisfaction as either "Excellent" or "Very good" in the study group. At post-intervention in the control group, there was no significant difference in the ratings of the mothers' satisfaction (Table 4).

At pre-intervention, $92.7 \%$ and $98 \%$ of respondents in study and control groups respectively were willing to re-attend the facility for immunization and there was no significant change at post intervention. More than $90 \%$ of respondents $(96.0 \%$ and $97.3 \%)$ in both study and control groups were willing to recommend someone else to attend immunization in the same facility with no significant increase in the proportion in both groups at post intervention $(p>0.05)$ (Table 5).

\section{DISCUSSION}

The respondents' age ranged between 16 -48 years which falls within the reproductive age group and this is expected as the respondents were the mothers. In this study, age was found to be an important socio-demographic factor that influenced the mothers' satisfaction with service at the immunization clinic $(p<0.05)$. The younger mothers were more satisfied than the older mothers. Educational level was also found to be a significant factor that influenced mothers' satisfaction with service received $(\mathrm{p}<0.05)$. Those that had less education were more satisfied.

Demographic factors have been documented to make a difference in perceived hospital quality of care with findings reported in an earlier study where age, health status and race (among demographic status) had significant 
effect on patient satisfaction $(16,17)$. Educational level of patient was found to be an important factor on patients' perception of quality in another study where health workers gave necessary information to clients if they perceived they were formally educated (18). The educational level as a factor is not surprising since education brings about more exposure and makes expectation higher. A study in Ibadan (Nigeria), however did not report sociodemographic factor as a predictor of satisfaction among women receiving antenatal care (8). This also may be due to the fact that the study was carried out at a tertiary health facility where it is expected that service is rated better.

More than $70 \%$ of respondents in this study were satisfied with the waiting time at health facilities pre and post intervention stages. At post intervention however, there was a significant increase in the respondents that were satisfied in the study group which can be attributable to the intervention (adding an additional day for immunization service) in the study. This is likely to have reduced the number of children to be immunized at each visit compared to when immunization service was provided once in a week. Similar finding was reported in an intervention program where approximately $90 \%$ of respondents had rated their appointments as timely since the appointments were scheduled on the computers (19). Findings from other studies have also reported waiting times as satisfactory despite the respondents describing them as long $(8,20)$. The perception of clients and their satisfaction may likely depend on the service they have come to utilize at the health facility.

The effect of sensitization of health workers in the study group facility reflected in the satisfaction with provision of seats and information provided in addition to the waiting times among the mothers in the study group at post-intervention stage and this was statistically significant $(p<0.05)$ but this was not the case at the control site. This is not unexpected because there were lesser children and hence mothers at each visit implying more space on the seats due to addition of an extra day to immunization though the facility did not purchase more seats.

Over $90 \%$ of mothers in both study and control groups were generally satisfied with the service they had received at the pre-intervention (Other studies have also reported high rates of satisfaction among respondents $(8.21,22)$ and post intervention stages. Overall satisfaction was generally high and this suggests that there are some other factors that affect patients satisfaction with service received in a health facility as documented by other studies $(16,23,24)$. Previous studies in Ibadan, Ilorin, have also documented high satisfaction figures $(8,25)$ despite lower satisfaction with individual components of the process. Could this suggest that health services are generally bad or fair and so anything that is fair is generally acceptable and would give client satisfaction? These findings may support thoughts from previous studies which suggest that client satisfaction with health services is not associated with the performance of process (26), satisfaction may be associated with such factors as satisfaction of the hospital staff and the work environment of the hospital staff $(6,27)$. However, satisfaction lower than $70 \%$ among respondents have been reported in Bangladesh and Ethiopia $(28,29)$.

Ratings of satisfaction by mothers significantly increased at post-intervention and this is in agreement with other findings, which have suggested that customer service initiatives in health care have become a popular way of attempting to improve patient satisfaction $(30,31)$.

This study indicates that more than $90 \%$ of mothers (both in study and control groups) were willing to re-attend immunization in the same health facility and also to recommend someone else to attend at pre-intervention stage with no significant increase in either the study or control group at post intervention. This may imply that some other factors may be responsible for a patients' willingness to attend a facility (28). There is no significant change because of the already high willingness to re-attend since there are little alternatives to receive such services in developing countries. Factors identified by Andaleeb included closeness to home, referral by family and friends and other miscellaneous factors which this study did not consider.

The findings in this study revealed that overall satisfaction with service received was high, age and educational status influenced mothers' satisfaction with immunization service. In conclusion, mothers of children became more satisfied (statistically significant $\mathrm{p}<0.05$ ) with waiting time, seat provision and information received on immunization after sensitization of health workers on quality health service. Health workers' sensitization had no significant increase in mothers' satisfaction with the way they were treated by health workers, overall satisfaction and willingness to re-attend the health facility ( $>>0.05$ ).

The limitation of this study is that it 
considered satisfaction alone as an outcome measure of quality of care which is subjective. Considering other aspects such as structure and technical competence and particularly introducing an observatory component may provide a more objective assessment of health service and a broader scope of quality for this service.

It is therefore recommended that sensitization of health workers towards quality health service may be necessary in order to generate options in service provision and improve client or patient satisfaction.

Conflict of interest: The authors declare no conflict of interest.

\section{REFERENCES}

1. Hughes RG. Tools and Strategies for Quality Improvement and Patient Safety. In: Hughes RG, editor. Patient Safety and Quality: An Evidence-Based Handbook for Nurses [Internet]. Rockville (MD): Agency for Healthcare Research and Quality (US); 2008 [cited 2016 Nov 30]. (Advances in Patient $\mathrm{S}$ a f e t y). A va i lable from : http://www.ncbi.nlm.nih.gov/books/NBK268 2/

2. Donabedian A. Evaluating the Quality of Medical Care: Evaluating the Quality of Medical Care. Milbank Q [Internet]. 2005 Dec [cited 2016 Nov 30];83(4):691-729. Available from: http://doi.wiley.com/10.1111/j.14680009.2005.00397.x

3. Prakash B. Patient satisfaction. J Cutan Aesthetic Surg [Internet]. 2010 [cited 2016 Nov 30];3(3):151. Available from: http://www.jcasonline.com/text.asp?2010/3/3/ $151 / 74491$

4. Increasing Immunization Coverage at the Health Facility Level [Internet]. The Communication Initiative Network. [cited 2016 Jun 11]. Available from: http://www.comminit.com/worldhealthorgani zation/content/increasing-immunizationcoverage-health-facility-level

5. Al-Abri R, Al-Balushi A. Patient Satisfaction Survey as a Tool Towards Quality Improvement. Oman Med J [Internet]. 2014 Jan 15 [cited 2016 Nov 30];29(1):3-7. A v a i l a b l e f $\mathrm{rom}$ : http://www.omjournal.org/fultext_PDF.aspx? DetailsID=467\&type $=$ fultext

6. Otani K, Herrmann PA, Kurz RS. Improving patient satisfaction in hospital care settings. Health Serv Manage Res [Internet]. 2011 Nov 1 [cited 2016 Nov 30];24(4):163-9. Available $\mathrm{f} \quad \mathrm{r} \quad \mathrm{o} \quad \mathrm{m}$ : http://hsm.sagepub.com/lookup/doi/10.1258/ hsmr.2011.011008
7. Mendoza Aldana J, Piechulek H, al-Sabir A. Client satisfaction and quality of health care in rural Bangladesh. Bull World Health Organ [Internet]. 2001 [cited 2016 Jun 11];79(6):512-7. Available from: http://www.ncbi.nlm.nih.gov/pmc/articles/P MC2566452/

8. Nwaeze IL, Enabor OO, Oluwasola T a. O, Aimakhu CO. Perception and satisfaction with quality of antenatal care services among pregnant women at the university college hospital, ibadan, Nigeria. Ann Ib Postgrad Med. 2013 Jun;11(1):22-8.

9. Luman ET, McCauley MM, Shefer A, Chu SY. Maternal characteristics associated with vaccination of young children. Pediatrics. 2003 May;111(5 Pt 2):1215-8.

10. Malata M. First-time mothers' satisfaction with labor and childbirth information received: A Malawian perspective. Clin Excell Nurse Pract [Internet]. 2000 Apr 1 [cited 2016 Jun 11];4(2):83-9. Available from: https://www.researchgate.net/publication/122 $\begin{array}{lllllllllll}5 & 2 & 7 & 3 & 4 & - & \mathrm{F} & \mathrm{i} & \mathrm{r} & \mathrm{s} & \mathrm{t}\end{array}$ time_mothers'_satisfaction_with_labor_and_ childbirth_information_received_A_Malawia n_perspective

11. Asprey A, Campbell JL, Newbould J, Cohn S, Carter M, Davey A, et al. Challenges to the credibility of patient feedback in primary healthcare settings: a qualitative study. $\mathrm{Br} \mathbf{J}$ Gen Pract [Internet]. 2013 Mar 1 [cited 2016 Nov 30];63(608):200-8. Available from: http://bjgp.org/cgi/doi/10.3399/bjgp13X6642 52

12. Manary MP, Boulding W, Staelin R, Glickman SW. The Patient Experience and Health Outcomes. N Engl J Med [Internet]. 2013 Jan 17 [cited 2016 Jun 11];368(3):201-3. A v a i l a b l e f r o m : http://www.nejm.org/doi/abs/10.1056/NEJMp 1211775

13. Ilorin. In: Wikipedia, the free encyclopedia [Internet]. 2016 [cited 2016 Jun 11]. Available $\begin{array}{lccc}\mathrm{f} & \mathrm{r} & \mathrm{o} & \mathrm{m}\end{array} \mathrm{\text { }}$ rin\&oldid=722833022

14. Kwara State Ministry of Health. Demography of Kwara State.

15. Kirkwood B, Sterne J. Essentials of Medical Statistics. 2 edition. Malden, Mass: WileyBlackwell; 2001.512 p.

16. Xesfingi S, Vozikis A. Patient satisfaction with the healthcare system: Assessing the impact of socio-economic and healthcare provision factors. BMC Health Serv Res [Internet]. 2016 Dec [cited 2016 Nov 30];16(1). Available from: http://www.biomedcentral.com/14726963/16/94

17. Dansereau E, Masiye F, Gakidou E, Masters SH, Burstein R, Kumar S. Patient satisfaction and perceived quality of care: evidence from a 
cross-sectional national exit survey of HIV and non-HIV service users in Zambia. BMJ Open [Internet]. 2015 Dec [cited 2016 Nov 30];5(12):e009700. Available from: http://bmjopen.bmj.com/lookup/doi/10.1136/ bmjopen-2015-009700

18. Sofaer S, Firminger K. PATIENT PERCEPTIONS OF THE QUALITY OF HEALTH SERVICES. Annu Rev Public Health [Internet]. 2005 Apr 21 [cited 2016 Nov 30];26(1):513-59. Available from: http://www.annualreviews.org/doi/10.1146/an nurev.publhealth.25.050503.153958

19. Martin L, Knight V, Ryder N, Lu H, Read PJ, McNulty A. Client feedback and satisfaction with an express sexually transmissible infection screening service at an inner-city sexual health center. Sex Transm Dis. 2013 Jan;40(1):70-4.

20. Hutchinson PL, Do M, Agha S. Measuring client satisfaction and the quality of family planning services: a comparative analysis of public and private health facilities in Tanzania, Kenya and Ghana. BMC Health Serv Res. 2011;11:203.

21. Chirdan OO, Lar LA, Afolaranmi TO, Inalegwu EO, Igoh CS, Adah GU. Client satisfaction with maternal health services comparism between public and private hospitals in Jos Nigeria. Jos J Med [Internet]. 2013 [cited 2016 Jun 11];7(1):1-9. Available $\begin{array}{lllll}\mathrm{f} & \mathrm{r} & \mathrm{o} & \mathrm{m}\end{array}$ http://www.ajol.info/index.php/jjm/article/vie w/89177

22. El Gammal HAAAR. Maternal satisfaction about childhood immunization in primary health care center, Egypt. Pan Afr Med J [Internet]. 2014 Jun 18 [cited 2016 Jun 11];18. A v a i l a b l e f r o m : http://www.ncbi.nlm.nih.gov/pmc/articles/P MC4236845/

23. Jaipaul CK, Rosenthal GE. Are older patients more satisfied with hospital care than younger patients? J Gen Intern Med. 2003 Jan;18(1):23-30.

24. Tokunaga J, Imanaka Y. Influence of length of stay on patient satisfaction with hospital care in Japan. Int J Qual Health Care J Int Soc Qual Health Care ISQua. 2002 Dec;14(6):493-502.

25. Ademola-Popoola DS, Akande TM, Idris A. Patients' assessment of quality of eye care in a nigerian teaching hospital. Niger Postgrad Med J. 2005 Sep;12(3):145-8.

26. Lyu H, Wick EC, Housman M, Freischlag JA, Makary MA. Patient satisfaction as a possible indicator of quality surgical care. JAMA Surg. 2013 Apr;148(4):362-7.

27. Aiken LH, Sermeus W, Van den Heede K, Sloane DM, Busse R, McKee M, et al. Patient safety, satisfaction, and quality of hospital care: cross sectional surveys of nurses and patients in 12 countries in Europe and the
United States. BMJ [Internet]. 2012 Mar 20 [cited 2016 Jun 11];344(mar20 2): e 1717-e1717. Available from: http://www.bmj.com/cgi/doi/10.1136/bmj.e17 17

28. Andaleeb SS, Siddiqui N, Khandakar S. Patient satisfaction with health services in Bangladesh. Health Policy Plan [Internet]. 2007 May 25 [cited 2016 Nov 30];22(4):263-73. Available from: https://academic.oup.com/heapol/articlelookup/doi/10.1093/heapol/czm017

29. Dagget T, Molla A, Belachew T. Job related stress among nurses working in Jimma Zone public hospitals, South West Ethiopia: a cross sectional study. BMC Nurs [Internet]. 2016 Dec [cited 2016 Nov 30];15(1). Available $\begin{array}{lllll}\mathrm{f} & \mathrm{r} & \mathrm{o} & \mathrm{m}\end{array}$ http://bmcnurs.biomedcentral.com/articles/10 $.1186 / \mathrm{s} 12912-016-0158-2$

30. Population Reports. Performance improvements 2002.2002 p. 19-21.

31. Tran TP, Schutte WP, Muelleman RL, Wadman MC. Provision of clinically based information improves patients' perceived length of stay and satisfaction with EP. Am J Emerg Med. 2002 Oct;20(6):506-9. 
Table 1: SOCIODEMOGRAPHIC CHARACTERISTICS OF RESPONDENTS

\begin{tabular}{|c|c|c|c|}
\hline Variables & $\begin{array}{l}\text { Study group }(\%) \\
(\mathrm{N}=150)\end{array}$ & $\begin{array}{l}\text { Control group (\%) } \\
(\mathrm{N}=150)\end{array}$ & $\begin{array}{l}\chi^{2} \\
p \text {-value } \\
\text { df } \\
\end{array}$ \\
\hline \multicolumn{4}{|l|}{ AGE GROUP } \\
\hline $16-20$ & $4 \quad(2.7)$ & $6(4.0)$ & \multirow{6}{*}{$\begin{array}{l}\chi^{2}=1.48 \\
p=0.9157 \\
d f=5\end{array}$} \\
\hline $21-25$ & $41(27.3)$ & $40(26.7)$ & \\
\hline $26-30$ & $63(42.0)$ & $58(38.7)$ & \\
\hline $31-35$ & $26(17.3)$ & $26(17.3)$ & \\
\hline $36-40$ & $12(8.0)$ & $13(8.7)$ & \\
\hline$>40$ & $4 \quad(2.7)$ & $7(4.6)$ & \\
\hline \multicolumn{4}{|c|}{ NO OF CHILDREN } \\
\hline 1 & $33(22.0)$ & $36(24.0)$ & \multirow{4}{*}{$\begin{array}{l}\chi^{2}=0.28 \\
p=0.9633 \\
d f=3\end{array}$} \\
\hline 2 & $39(26.0)$ & $40(26.7)$ & \\
\hline 3 & 37 (24.7) & $34(22.7)$ & \\
\hline$>3$ & $41 \quad(27.3)$ & $40(26.6)$ & \\
\hline \multicolumn{4}{|l|}{ OCCUPATION } \\
\hline Trader & $64(42.7)$ & $80(53.3)$ & \multirow{7}{*}{$\begin{array}{l}\chi^{2}=10.42 \\
d f=6 \\
p=0.1081\end{array}$} \\
\hline Tailor & 34 (22.7) & $26(17.3)$ & \\
\hline Housewife & $11(7.3)$ & $7(4.7)$ & \\
\hline Civil servants & $8 \quad(5.3)$ & $1(0.7)$ & \\
\hline Teaching & $6 \quad(4.0)$ & $5(3.3)$ & \\
\hline Student & $6 \quad(4.0)$ & $4(2.7)$ & \\
\hline Others & 21 & $27(18.0)$ & \\
\hline \multicolumn{4}{|c|}{ LEVEL OF EDUCATION } \\
\hline None & $55(36.7)$ & $56(37.3)$ & \multirow{4}{*}{$\begin{array}{l}\chi^{2}=0.43 \\
d f=3 \\
p=0.9334\end{array}$} \\
\hline Primary & $59 \quad(39.3)$ & $62(41.4)$ & \\
\hline Secondary & $25 \quad(16.7)$ & $21(14.0)$ & \\
\hline Post secondary & $11(7.3)$ & $11(7.3)$ & \\
\hline \multicolumn{4}{|l|}{ ETHNICITY } \\
\hline Yoruba & $124(82.7)$ & $135(90.0)$ & \multirow{3}{*}{$\begin{array}{l}\chi^{2}=3.42 \\
d f=2 \\
p=0.1804\end{array}$} \\
\hline Fulani & $17(11.3)$ & $10(6.7)$ & \\
\hline Others & $9 \quad(6.0)$ & $5(3.3)$ & \\
\hline \multicolumn{4}{|l|}{ RELIGION } \\
\hline Christianity & $24(16.0)$ & $12(8.0)$ & \multirow{2}{*}{$\begin{array}{l}\chi^{2}=3.82 \\
p=0.0507\end{array}$} \\
\hline Islam & $126(84.0)$ & $138(92.0)$ & \\
\hline \multicolumn{4}{|c|}{ MARITAL STATUS } \\
\hline Single & $5(3.3)$ & $9(6.0)$ & \multirow{2}{*}{$\begin{array}{l}\chi^{2}=0.67 \\
p=0.4115\end{array}$} \\
\hline Married & $145(96.7)$ & $141(94.0)$ & \\
\hline
\end{tabular}


Table 2: Respondents' satisfaction with service received

\begin{tabular}{|c|c|c|c|c|}
\hline \multirow[t]{2}{*}{ Client satisfaction } & \multicolumn{2}{|c|}{ STUDY GROUP } & \multicolumn{2}{|c|}{ CONTROL GROUP } \\
\hline & $\begin{array}{l}\text { Pre- } \\
\text { intervention } \\
\mathrm{N}=150(\%)\end{array}$ & $\begin{array}{l}\text { Post- } \\
\text { intervention } \\
(\mathrm{N}=150)\end{array}$ & $\begin{array}{l}\text { Pre- } \\
\text { intervention } \\
\mathrm{N}=150(\%)\end{array}$ & $\begin{array}{l}\text { Post- } \\
\text { intervention } \\
\mathrm{N}=150(\%)\end{array}$ \\
\hline \multicolumn{5}{|l|}{ Waiting time } \\
\hline Yes & $110(73.3)$ & $140(93.3)$ & $116(77.3)$ & $123(82.0)$ \\
\hline No & $\begin{array}{l}40(26.7) \\
\chi^{2}=20.40 \\
d f=1 \\
p=0.0001\end{array}$ & $10(6.7)$ & $\begin{array}{l}34(22.7) \\
\chi^{2}=0.74 \\
d f=1 \\
p=0.3894\end{array}$ & $27(18.0)$ \\
\hline \multicolumn{5}{|l|}{ Seats provided } \\
\hline Yes & 115(76.7) & 149(99.3) & $142(94.7)$ & 143(95.3) \\
\hline No & $\begin{array}{l}35(23.3) \\
\chi^{2}=34.38 \\
d f=1 \\
p=0.0001\end{array}$ & $* 1(0.7)$ & $\begin{array}{l}8(5.3) \\
\chi^{2}=0.00 \\
d f=1 \\
p=1.0000\end{array}$ & $7(4.7)$ \\
\hline \multicolumn{5}{|l|}{$\begin{array}{l}\text { Information received } \\
\text { on immunization }\end{array}$} \\
\hline Yes & 137(91.3) & $150(100)$ & 134(89.3) & 132(88.0) \\
\hline No & $\begin{array}{l}13(8.7) \\
\chi^{2}=11.58 \\
d f=1 \\
p=0.0007\end{array}$ & $* 0$ & $\begin{array}{l}16(10.7) \\
\chi^{2}=0.03 \\
d f=1 \\
p=0.8555\end{array}$ & $18(12.0)$ \\
\hline \multicolumn{5}{|l|}{$\begin{array}{l}\text { Way treated by the } \\
\text { health worker }\end{array}$} \\
\hline Yes & $144(96.0)$ & 148(98.7) & 145(96.7) & 144(96.0) \\
\hline No & $\begin{array}{l}6(4.0) \\
\chi^{2}=1.16 \\
d f=1 \\
p=0.2824\end{array}$ & $* 2(1.3)$ & $\begin{array}{l}5(3.3) \\
\chi^{2}=0.00 \\
d f=1 \\
p=1.0000\end{array}$ & $6(4.0)$ \\
\hline $\begin{array}{l}\text { Service } \\
\text { today }\end{array}$ & & & & \\
\hline Yes & 147(98.0) & $150(100)$ & 147(98.0) & 148(98.7) \\
\hline No & $\begin{array}{l}* 3(2.0) \\
\chi^{2}=1.35 \\
d f=1 \\
p=0.2475\end{array}$ & $* 0$ & $\begin{array}{l}* 3(02.0 \\
\chi^{2}=0.00 \\
d f=1 \\
p=1.0000\end{array}$ & $* 2(1.3)$ \\
\hline
\end{tabular}


Table 3: Relationship between socio-demographic characteristic and respondents' satisfaction

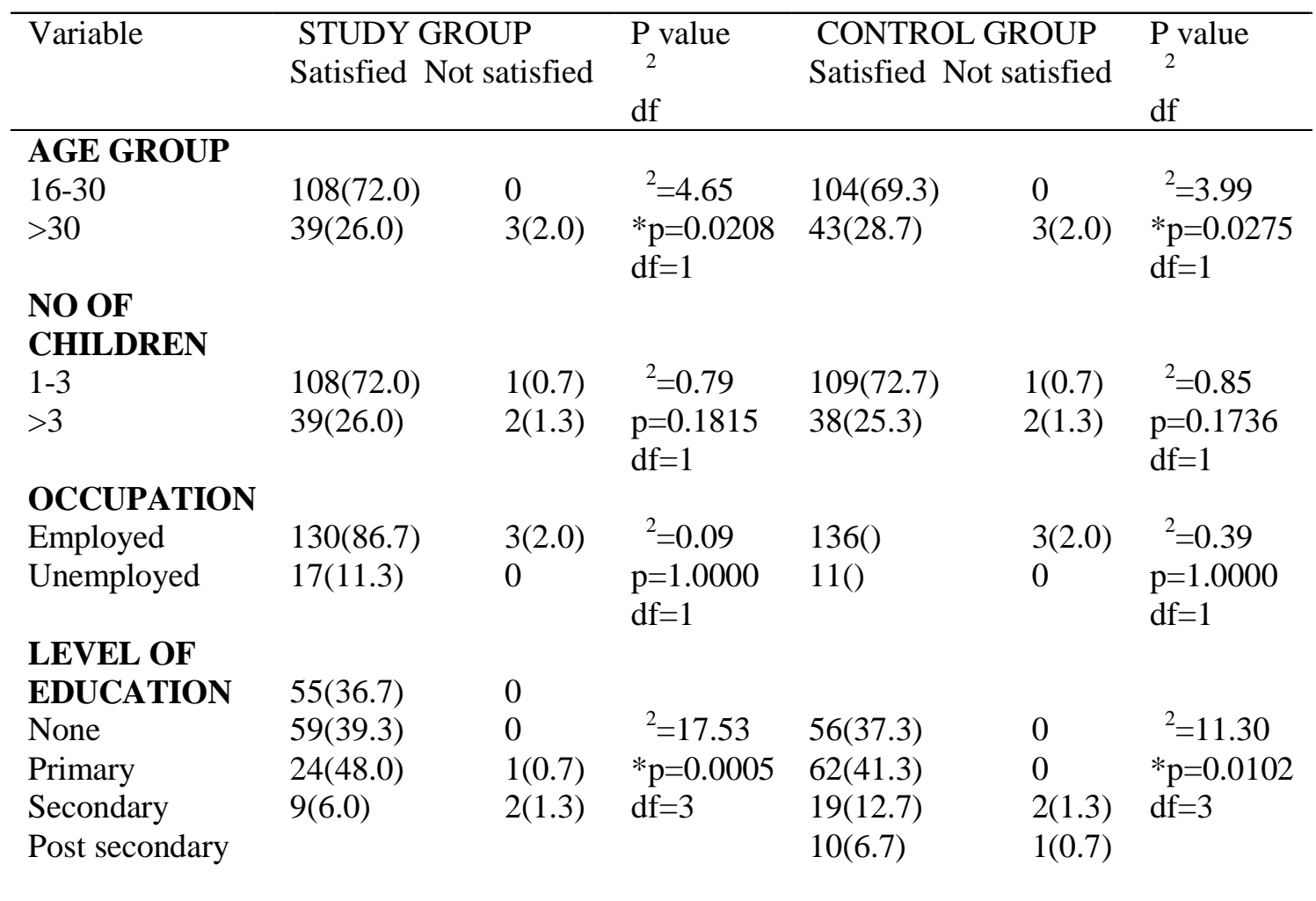

$*=$ where $\mathrm{p}$ is statistically significant

Table 4: Respondents' rating of level of over-all satisfaction with care received

\begin{tabular}{|c|c|c|c|c|}
\hline \multirow{2}{*}{$\begin{array}{l}\text { Level of } \\
\text { satisfaction }\end{array}$} & \multicolumn{2}{|c|}{ STUDY GROUP } & \multicolumn{2}{|c|}{ CONTROL GROUP } \\
\hline & $\begin{array}{l}\text { Pre- } \\
\text { intervention } \\
\mathrm{N}=150(\%)\end{array}$ & $\begin{array}{l}\text { Post- } \\
\text { intervention } \\
\mathrm{N}=150(\%)\end{array}$ & $\begin{array}{l}\text { Pre- } \\
\text { intervention } \\
\mathrm{N}=150(\%)\end{array}$ & $\begin{array}{l}\text { Post- } \\
\text { intervention } \\
\mathrm{N}=148(\%)\end{array}$ \\
\hline Excellent & $16(10.7)$ & $56(37.3)$ & $14(9.3)$ & $13(8.8)$ \\
\hline Very good & $53(35.3)$ & $81(54.0)$ & $59(39.3)$ & $65(43.9)$ \\
\hline Good & $64(42.6)$ & 13(8.7) & $54(36.0)$ & $51(34.5)$ \\
\hline Fair & $16(10.7)$ & 0 & $17(11.4)$ & $19(12.8)$ \\
\hline Poor & $1(0.7)$ & 0 & $6(4.0)$ & 0 \\
\hline
\end{tabular}


Table 5: Distribution of respondents by willingness to re-attend immunization clinic in the same health facility

\begin{tabular}{|c|c|c|c|c|}
\hline \multirow{2}{*}{$\begin{array}{l}\text { Attendance of the } \\
\text { same health facility } \\
\text { for immunization }\end{array}$} & \multicolumn{2}{|c|}{ STUDY GROUP } & \multicolumn{2}{|c|}{ CONTROL GROUP } \\
\hline & $\begin{array}{l}\text { Pre- } \\
\text { intervention } \\
(\mathrm{N}=150)\end{array}$ & $\begin{array}{l}\text { Post } \\
\text { intervention } \\
(\mathrm{N}=150)\end{array}$ & $\begin{array}{l}\text { Pre- } \\
\text { intervention } \\
(\mathrm{N}=150)\end{array}$ & $\begin{array}{l}\text { Post- } \\
\text { intervention } \\
\qquad(\mathrm{N}=150)\end{array}$ \\
\hline $\begin{array}{l}\text { Will want to re- } \\
\text { attend }\end{array}$ & & & & \\
\hline Yes & $139(92.7)$ & $147(98.0)$ & $147(98.0)$ & $147(98.0)$ \\
\hline No & $\begin{array}{l}11(7.3) \\
\chi^{2}=3.67 \\
\mathrm{df}=1 \\
\mathrm{p}=0.0554\end{array}$ & $3(2.0)$ & $\begin{array}{l}3(2.0) \\
\chi^{2}=0.17 \\
\mathrm{df}=1 \\
\mathrm{p}=1.0000\end{array}$ & $3(2.0)$ \\
\hline $\begin{array}{l}\text { Will recommend } \\
\text { someone to attend }\end{array}$ & & & & \\
\hline $\begin{array}{l}\text { Yes } \\
\text { No }\end{array}$ & $\begin{array}{l}144(96.0) \\
6(4.0) \\
\chi^{2}=0.10 \\
d f=1 \\
p=0.7477\end{array}$ & $\begin{array}{l}146(97.3) \\
4(2.7)\end{array}$ & $\begin{array}{l}146(97.3) \\
4(2.7) \\
\chi^{2}=0.00 \\
\mathrm{df}=1 \\
\mathrm{p}=1.0000\end{array}$ & $\begin{array}{l}147(98.0) \\
3(2.0)\end{array}$ \\
\hline
\end{tabular}

